Statement by the Managing Director on the Work Program of the Executive Board - Executive Board Meeting, November 24, 2008 


\section{Statement by the Managing Director on the Work Program of the Executive Board November 24, 2008}

1. The global economy is going through a period of unprecedented financial instability. The Fund has been asked by the IMFC to play a leading role in helping the membership both to deal with the immediate crisis and work towards a new strengthened global architecture. These tasks are well within our mandate. Addressing these challenges - and doing so within a compressed timeframe - will require strict prioritization on three key areas: (i) providing policy advice and timely financial support that meets members' needs; (ii) understanding what went wrong; (iii) and assembling the building blocks of a new international financial architecture.

2. In the tight, post-restructuring, budgetary environment, meeting these front-line challenges will be difficult and require exceptional focus and commitment. The high priority assigned to advancing this work in the period to the Spring 2009 IMFC meetings - and the priority to be assigned to Board consideration of members' requests for use of Fund resources - may necessitate adjustments to other parts of the work program, and will require careful monitoring by staff and management working closely with Executive Directors. ${ }^{1}$

\section{Restoring Global Financial Stability}

\section{A. Fund Programs and Lending}

3. Emergency financing. More and more emerging market and developing countries are being hit by the fallout from the financial crisis in advanced economies. The Fund has been, and will continue to, deploy its lending resources in substantial amounts both rapidly and flexibly, with conditionality tailored on the priorities to address the crisis. As individual country cases arise, I will also continue to activate emergency procedures as warranted, in consultation with the Executive Board, to allow requests for use of Fund resources to be considered by the Board in a matter of days.

4. Reforming our instruments. Before the Annual Meetings, we agreed on a road map for reviewing various aspects of our lending role. Reflecting the IMFC's call to accelerate this timeline where there is strong consensus and particular urgency, we have already established a new Short-Term Liquidity Facility (SLF) to help countries cope with very short-term and self-correcting external liquidity pressures arising from external market developments despite strong underlying fundamentals and domestic policies. The Board will also consider before the turn of the year papers on Access Limits (A.1) and Charges and Maturities (A.2). These will be supplemented by discussions on Analytical Considerations (A.3), which will examine the Fund's lending role (e.g., market failures, the balance of

\footnotetext{
${ }^{1}$ Paragraphs 3-8 outline how this focus and commitment will translate into the Board's work program. Paragraphs 9-17 highlight other key areas of the work program, some with a longer-term timeframe. The parenthetical citations refer to the comprehensive listing of items set out in the Attachment.
} 
payments need criterion for Fund lending etc.), and the scope for innovation and streamlining of instruments. A closely related paper on Conditionality (A.4) will follow shortly thereafter. (The review of the Fund's lending role in low-income countries is taken up as part of our continuing work program.) These papers will be informed by broad and inclusive consultations with members and others; staff are planning seminars with inside and outside participation. This is a broad agenda with many difficult issues, and we may not reach decisions right away in all these areas. We have already made a good start with the SLF, and I expect to draw together the building blocks from these discussions in a Stock-Taking paper (A.5) before the next Annual Meetings.

\section{B. The Path Out of the Crisis}

5. Understanding what happened. The massive scale of the crisis and its costs have taken a great many by surprise. It has become imperative to fully understand the complex chain of causes and effects that led to this cataclysm, to draw appropriate lessons and prevent such toxic mechanisms from operating again in future - undertakings the IMFC asked the Fund to take the lead on. Thus, I have requested RES, drawing upon the newly established Macro-Financial Unit in RES, along with SPR, MCM and FAD, to provide an analysis of the Causes of the Crisis and Lessons for Macroeconomic Policy and Regulation (B.1). I see this paper as a key input for our future work and, of course, for the next IMFC meeting. A Board seminar on the Fiscal Implications of the Financial Crisis will also contribute to our understanding of the repercussions of the current crisis (B.2).

6. Foundations of a new financial architecture. I look forward to participating in the emergency summit meeting of G-20 leaders set for November 15 to discuss the financial crisis. This meeting will likely be the first in a series of international meetings intended to lay the groundwork for a possible overhaul of the rules governing financial markets - Bretton Woods II. The Fund - with its universal membership, core macro-financial expertise, and mandate to promote international cooperation - must be prepared to participate fully in this dialogue. The international community's reflection on a possible new architecture will need to be informed by the lessons from the current crisis and also come to grips cooperatively with various cross-border issues. The membership has asked the Fund to help coordinate this effort, drawing on the expertise of others to ensure a wide range of perspectives. I see the Fund as having the unique responsibility and latitude to allow the membership to delve into these issues, and to provide the "machinery for consultation and collaboration" set out in the Fund's Articles of Agreement. The Board will be engaged early on in the process. The larger challenge - once all relevant parties have been brought together-will be to embed various initiatives into a unified framework for safeguarding global macroeconomic and financial stability.

7. Getting ahead of the curve. Staff will continue to engage with members and monitor developments closely, paying special attention to vulnerable countries. This work will include:

- Timely integrated updates. To move beyond the customary one country-at-a-time format, we have initiated, on a trial basis, new Area Department Updates (B.3) to communicate informally staff assessments of developments in regions, bringing a cross-country and 
regional perspective with the flexibility to include country specifics. In the same vein, efforts will be made to better integrate country-level analysis in the WEMD Board presentations of MCM and RES (B.4).

- Early warning. High priority must be given to sharing with the Board the key elements of staff's work on Early Warning Systems and advanced country vulnerabilities. An informal briefing on Progress with Early Warnings (B.5) will provide a snapshot of common themes arising from the vulnerability exercise and its extension to advanced economies; more generally, the findings of staff's work on risk assessments relevant to global or regional stability will be brought to the Board's attention in a format consistent with the sensitivity of such work.

- Other emerging issues. Staff will strive to anticipate emerging issues and bring them to the Board's attention. For example, effective crisis management and bank insolvency frameworks will evidently be key to contain the damage from the current market upheaval. Extensive staff work is underway in this area, including a reflection (with the World Bank) on the design of legal and regulatory frameworks for bank insolvency; analytical work on crisis management frameworks in industrial countries; and studies on the treatment of non-depository institutions and the systemic risks posed by their failure, insolvency issues involving derivatives, on the legal and regulatory framework for crossborder bank insolvency, and on capital adequacy issues arising from recapitalizations and equity investments (government and private). The findings will be presented to the Executive Board for discussion in a seminar (B.6).

- Impact on LICs. The global financial crisis is a further threat to the macroeconomic and financial stability of LICs, many of whom were already under severe strain from high food and fuel prices. We intend to monitor closely the impact of these overlapping shocks; the aggregate impact may be severe in some cases depending on initial conditions, trade structures, and financial links with the outside world. A staff paper will review the actual and potential impacts of the financial crisis on LICs, including prospects for macroeconomic stability, growth, balance of payments positions, and financial sector soundness (B.7). Close monitoring of the macroeconomic impact of higher food and fuel prices will continue.

8. Quota and voice and the new income model. Even while we deal with this financial crisis, we should not forget that the IMFC called on all members to work urgently toward the early completion of the domestic legislative steps required to make effective the quota and voice reforms and the Fund's new income model. Timely action by members will enhance the Fund's legitimacy, credibility, and effectiveness.

\section{Continuing Work OF THE Fund}

9. Further prioritization. We also need to prioritize our continuing work agenda. Higher priority items are described in the following text. The attachment provides a comprehensive listing of the work program. 


\section{Advancing Surveillance Priorities}

10. Economic priorities. The Statement of Surveillance Priorities for 2008-11 adopted by the Board just before the Annual Meetings, and subsequently endorsed by the IMFC, identifies four priorities for the next three years: (i) resolving financial market distress; (ii) strengthening the global financial system; (iii) adjusting to sharp changes in commodity prices; and (iv) promoting the orderly reduction of global imbalances. In addition to the actions discussed above, these priorities will be reflected in the staff's work program and regular outputs on bilateral, regional, and multilateral surveillance. More specifically:

- The GFSR will focus in its analysis of global financial stability and policy recommendations on the implications of the de-leveraging process for credit creation and linkages across institutions and countries. It will also contribute to the ongoing development of the Fund's early warning methodologies by examining the fundamentals of affected institutions, indicators of market stress, counter-party linkages, and prevailing global financial conditions. Relatedly, the WEO analytical chapters will study the conditions for economic recovery from financial stress for advanced economies and the transmission of financial stress from advanced to emerging market and developing economies, and the implications for their economic policies. Consideration is being given to issuing a joint "global outlook" statement that will provide a coherent overall synthesis of the GFSR and WEO.

- A special Review of the Stability of the Global Exchange Rate System, the first since 1999, will give the Board an opportunity to reflect on the role of reserve currencies and the implications of members' choice of exchange rate regime for macroeconomic performance and the smooth functioning of the overall system of exchange rates.

11. Operational priorities. Like the economic priorities, the operational priorities for the next three years set forth in the Statement of Surveillance Priorities - (i) risk assessment; (ii) financial sector surveillance and real-financial linkages; (iii) multilateral perspective; and

(iv) analysis of exchange rates and external stability risks - will directly affect the conduct of surveillance work at the multilateral, regional, and bilateral levels. Along with other conclusions of the Triennial Surveillance Review, they will be reflected in a revised Surveillance Guidance Note and a more specific Financial Sector Surveillance Guidance Note to be circulated for information. Further:

- A Review of the Financial Sector Assessment Program (joint with the World Bank) will be an opportunity to reassess how the FSAP might need to be adapted against the background of earlier work on the lessons from the financial crisis and evolving ideas on the global financial architecture. The objective would be to integrate better FSAP analysis into Article IV surveillance and inform broader financial sector surveillance by increasing the focus on higher risk issues or countries and enhancing the emphasis on cross-border spillovers, while streamlining processes. In collaboration with the Bank staff, analytical and empirical work (including outreach and fact-gathering efforts with our membership) is planned to begin in early 2009. 


\section{Fund Support for Low-Income Countries}

12. Policy and financial support. In line with the Fund's strategic refocusing, the specific forms of our policy and financial engagement with LICs will be adapted and tailored to their evolving needs.

- On policy support, we plan to undertake a series of analytical studies that respond to issues of growing macroeconomic importance in many LICs, including capital flows, robust medium-term public debt management strategies, financial market development, and the design of monetary regimes.

- Fund policies on external financing will be reviewed in light of changes in the pattern of LIC financing, and possible implications drawn for program conditionality. As part of the broader review of Fund facilities, and building upon the recent reform of the ESF, the adequacy of the Fund's instruments for supporting LICs will be assessed; this will include consideration of potential new instruments, streamlining of existing ones, and a review of the Fund's concessional financing framework. The role of the PSI will also be assessed in this context, based on a review of experience under the instrument. In light of the outcome of the facilities review, the Fund's approach to supporting fragile states will be revisited. This work agenda will be coordinated by the LIC Unit in SPR.

13. Capacity Building. The Board will be kept informed regularly on progress with reforms in technical assistance and fundraising. Work is underway on enhancing the TA performance measurement system to systematically track results in the field (results-focused management); on improving costing for technical assistance; and on introducing a new country contribution policy in May 2009. A guidance note for staff to operationalize wider dissemination of TA information, effective January 1, 2009, will be sent to the Board for information. Staff will submit to the Executive Board a proposal for a new framework instrument for external financing, which will provide more flexibility and broader coverage for external financing. Requests to open multi-donor subaccounts for a new regional TA center in Central America, a new trust fund on AML/CFT, and a framework agreement with the European Commission will also be submitted.

\section{E. Modernizing the Fund}

14. Governance. A joint Steering Committee of a group of Executive Directors and management will be operational shortly. It will serve to coordinate and monitor the various prongs of the work program related to IMF governance reform, and facilitate a productive dialogue within the Fund and with interested external parties. The timing of the Steering Committee's work, on which the Board will be briefed periodically, will need to take account of the report of Trevor Manuel's Committee on IMF Governance Reform, which is expected by next April.

15. Income model. We must continue our preparations to implement the new income model in a timely manner once the legal basis is secured. The Board will discuss shortly the adequacy of the Fund's precautionary balances including under the new income model. This paper seeks Directors' views on the broad outlines of a possible new framework for reserve 
accumulation and dividend payments. Later this year, the Board will explore considerations for broadening the Fund's investment mandate, examining the performance of potential alternative asset classes.

16. Budget reform. Better costing of key outputs and a closer alignment of departmental business plans with strategic priorities are essential elements of the next phase of budget reforms. Proposals are being developed for consideration by the Committee on the Budget on the introduction of activity-based costing, supported by the use of greater detail in staff costs, as well as the carry forward of unspent budget allocations.

17. Reporting to the IMFC. I intend to replace my "umbrella report" with a short, focused Managing Director's Statement to the IMFC on the IMF's Policy Agenda that lays out our forward-looking agenda. This format was well received last time and is more accessible to Fund Governors. At the same time, to brief the IMFC on progress with the IMF's policy agenda since its last meeting, a table of key Fund outputs over the previous six months will be circulated (under the same modalities as the "umbrella report"). 
Fall 2008 Work Program Statement

ATTACHMENT

\begin{tabular}{|c|c|c|c|c|}
\hline Title & Type & Description & Dept. & Date \\
\hline \multicolumn{5}{|c|}{ I. RESTORING GLOBAL FINANCIAL STABILITY } \\
\hline \multicolumn{5}{|l|}{ A. Fund Programs and Lending } \\
\hline $\begin{array}{l}\text { A.1 Limits on Access for Use of } \\
\text { Fund Resources. }\end{array}$ & DIS & Examines the case for increasing access limits. & SPR/FIN & $\begin{array}{l}\text { Nov. } \\
2008\end{array}$ \\
\hline $\begin{array}{l}\text { A. } 2 \text { Review of Surcharges and } \\
\text { Maturities under the New Income } \\
\text { Model. }\end{array}$ & DIS & $\begin{array}{l}\text { Considers proposals to reform surcharges and eliminate } \\
\text { time-based repurchase expectations. }\end{array}$ & SPR/FIN & $\begin{array}{l}\text { Nov. } \\
2008\end{array}$ \\
\hline $\begin{array}{l}\text { A. } 3 \text { Review of the Fund's Financing } \\
\text { Role in Member Countries- } \\
\text { Analytical Considerations. }\end{array}$ & DIS & $\begin{array}{l}\text { Examines a range of issues such as markets gaps, the } \\
\text { coherence of the Fund's lending framework, and the } \\
\text { balance of payments criterion for lending, as well as the } \\
\text { scope for innovation in instruments (including the case for } \\
\text { a crisis prevention instrument) and their streamlining. }\end{array}$ & $\begin{array}{l}\mathrm{RES} / \mathrm{SPR} / \\
\mathrm{MCM}\end{array}$ & TB2 \\
\hline $\begin{array}{l}\text { A.4 Review of the Fund's Lending } \\
\text { Role in Member Countries, Re- } \\
\text { examining Conditionality }\end{array}$ & DIS & $\begin{array}{l}\text { Explores new approaches to conditionality while still } \\
\text { providing adequate safeguards for Fund resources. }\end{array}$ & $\mathrm{SPR} / \mathrm{LEG}$ & TB2 \\
\hline $\begin{array}{l}\text { A.5 Stock-Taking on Reforming the } \\
\text { Fund's Financing Instruments and } \\
\text { Policies. }\end{array}$ & DIS & $\begin{array}{l}\text { Pulls together building blocks from earlier papers on } \\
\text { Review of the Fund's Lending Role in Member Countries } \\
\text { to set the stage for decisions before the } 2009 \text { Annual } \\
\text { Meetings. }\end{array}$ & SPR & TB3 \\
\hline \multicolumn{5}{|l|}{ B. The Path Out of the Crisis } \\
\hline $\begin{array}{l}\text { B.1 Causes of the Crisis and } \\
\text { Lessons for Macroeconomic Policy } \\
\text { and Regulation }\end{array}$ & DIS & $\begin{array}{l}\text { Analyzes the complex chain of causes and effects that led } \\
\text { to the financial crisis. }\end{array}$ & $\begin{array}{l}\mathrm{RES} / \mathrm{MCM} / \\
\mathrm{SPR}\end{array}$ & $\begin{array}{l}\text { TB1/ } \\
\text { TB2 }\end{array}$ \\
\hline $\begin{array}{l}\text { B.2 Fiscal Implications of the } \\
\text { Financial Crisis. }\end{array}$ & SEM & $\begin{array}{l}\text { Examines the implications of fiscal policy for fiscal } \\
\text { sustainability and government's contingent liabilities. }\end{array}$ & FAD & $\mathrm{TB} 1 / \mathrm{TB} 2$ \\
\hline B.3 Area Department Updates & IB & $\begin{array}{l}\text { Communicates staff assessments of developments and } \\
\text { necessary policies in countries. }\end{array}$ & $\begin{array}{c}\text { Area } \\
\text { Departments }\end{array}$ & $\begin{array}{l}\text { TB1/ } \\
\text { TB2/ } \\
\text { TB3 }\end{array}$ \\
\hline $\begin{array}{l}\text { B.4 GFSR Market } \\
\text { Update/WEMD/WEO Quarterly } \\
\text { Update. }\end{array}$ & ISEM & $\begin{array}{l}\text { Presents the evolution of risks to global financial stability } \\
\text { and progress in resolving financial crisis; the WEO } \\
\text { quarterly note will update forecasts for key countries. }\end{array}$ & $\mathrm{MCM} / \mathrm{RES}$ & $\begin{array}{l}\text { TB1/ } \\
\text { TB2/ } \\
\text { TB3 }\end{array}$ \\
\hline B.5 Progress with Early Warnings. & IB & $\begin{array}{l}\text { Provide a snapshot of cross-country findings from the } \\
\text { vulnerability exercise, and progress report on } \\
\text { vulnerability exercise for advanced economies. }\end{array}$ & RES/SPR & TB2 \\
\hline $\begin{array}{l}\text { B.6 Legal and Regulatory } \\
\text { Frameworks for Bank Insolvency. }\end{array}$ & ISEM & $\begin{array}{l}\text { Reviews best practices in designing legal and regulatory } \\
\text { frameworks for bank insolvency. }\end{array}$ & LEG/MCM & TB1 \\
\hline $\begin{array}{l}\text { B. } 7 \text { The Impact of the Global } \\
\text { Financial Crisis on Low-Income } \\
\text { Countries. }\end{array}$ & IB & $\begin{array}{l}\text { Discusses the actual or potential impact of the financial } \\
\text { crisis on LIC economies, including prospects for their } \\
\text { growth, balance of payments positions, and financial } \\
\text { stability, as background (inter alia) to the review of LIC } \\
\text { facilities. }\end{array}$ & SRP & TB1 \\
\hline \multicolumn{5}{|l|}{ Abbreviations: } \\
\hline IB: informal briefing & IB: informal briefing & \multicolumn{3}{|c|}{ ISEM: informal seminar } \\
\hline \multicolumn{2}{|l|}{ Departments: } & FIN: Finance & \multicolumn{2}{|c|}{ LEG: Legal } \\
\hline \multicolumn{2}{|l|}{ MCM: Monetary and Capital Markets } & SPR: Strategy, Policy, and Review & \multicolumn{2}{|c|}{ RES: Research } \\
\hline \multicolumn{5}{|l|}{ FAD: Fiscal Affairs Department } \\
\hline \multicolumn{2}{|l|}{$\begin{array}{l}\text { Time band } 1 \text { (TB1): now through } \\
\text { January } 2009\end{array}$} & Time band 2 (TB2): February-April 2009 & \multicolumn{2}{|c|}{ Time band 3 (TB3): After April 2009} \\
\hline
\end{tabular}


Fall 2008 Work Program Statement

\begin{tabular}{|c|c|c|c|c|}
\hline Title & Type & Description & Dept. & Date \\
\hline \multicolumn{5}{|c|}{ II. ThE CONTINUING WORK OF THE FUND } \\
\hline \multicolumn{5}{|c|}{ C. Advancing Surveillance Priorities } \\
\hline $\begin{array}{l}\text { C.1 GFSR/World Economic } \\
\text { Outlook/WEMD. }\end{array}$ & DIS & $\begin{array}{l}\text { The GFSR will continue to examine the de-leveraging } \\
\text { process and linkages across institutions. It will study } \\
\text { closely events that have become "systemic", attempting to } \\
\text { discern precursors. WEO will update economic } \\
\text { developments and outlook, focusing on conditions for } \\
\text { economic recovery from financial stress and implications } \\
\text { for economic policies. }\end{array}$ & $\mathrm{MCM} / \mathrm{RES}$ & TB2 \\
\hline $\begin{array}{l}\text { C. } 2 \text { Seventh Review of Data } \\
\text { Standards Initiatives. }\end{array}$ & DIS & $\begin{array}{l}\text { Reports on developments in the data standards initiatives } \\
\text { since the Sixth Review and proposes medium-term work } \\
\text { programs for the SDDS and GDDS. }\end{array}$ & STA & $\begin{array}{l}\text { Dec. } \\
2008\end{array}$ \\
\hline $\begin{array}{l}\text { C. } 3 \text { Classification of Exchange } \\
\text { Rate Arrangements. }\end{array}$ & Info & $\begin{array}{l}\text { Reviews the system and methodology used to classify } \\
\text { member countries' de facto exchange rate arrangements to } \\
\text { clarify the definitions of the various categories and } \\
\text { establish more operational and unambiguous criteria for } \\
\text { their application. }\end{array}$ & $\mathrm{MCM}$ & TB1 \\
\hline $\begin{array}{l}\text { C. } 4 \text { Review of Stability of System } \\
\text { of Exchange Rates. }\end{array}$ & ISEM & $\begin{array}{l}\text { Following the lEO report on the Fund's exchange rate } \\
\text { policy advice and building on earlier studies undertaken in } \\
1999 \text { and 2003, examines members' choice of exchange } \\
\text { rate regime, its implications for macroeconomic } \\
\text { performance and smooth functioning of the overall system } \\
\text { of exchange rates, and evolving role of reserve currencies. }\end{array}$ & $\mathrm{RES} / \mathrm{SPR}$ & TB2 \\
\hline C.5 FSAP Review. & DIS & $\begin{array}{l}\text { Reassess (in collaboration with the Bank) how the FSAP } \\
\text { will be adapted to help make financial sector surveillance } \\
\text { more effective, including by increasing the focus on higher } \\
\text { risk areas or grouped by countries or themes, enhancing the } \\
\text { emphasis on cross-border spillovers and risks, and by } \\
\text { streamlining processes. }\end{array}$ & $\mathrm{MCM} / \mathrm{SPR}$ & TB3 \\
\hline $\begin{array}{l}\text { C. } 6 \text { Anti-Money Laundering and } \\
\text { Combating the Financing of } \\
\text { Terrorism-Review of the } \\
\text { Effectiveness and Plans for the } \\
\text { Program. }\end{array}$ & DIS & $\begin{array}{l}\text { Examines the effectiveness of the AML/CFT program, } \\
\text { including the role of AML/CFT in strengthening Fund } \\
\text { surveillance and capacity building, and proposes work } \\
\text { plans. }\end{array}$ & LEG & TB3 \\
\hline \multicolumn{5}{|c|}{ D. Fund Support For Low-Income Countries } \\
\hline $\begin{array}{l}\text { D.1 External Financing Issues } \\
\text { Facing Low-Income Countries. }\end{array}$ & DIS & $\begin{array}{l}\text { Assesses how the financing environment facing LICs has } \\
\text { changed in recent years and draws implications for the } \\
\text { Fund's advice and policies on debt and external financing, } \\
\text { including possible options for change. }\end{array}$ & SPR & TB2 \\
\hline $\begin{array}{l}\text { D.2 Debt Management for Low- } \\
\text { and Middle-Income Countries: } \\
\text { Results from the Pilot Program. }\end{array}$ & DIS & $\begin{array}{l}\text { Reports on developments in the pilot program and proposes } \\
\text { next steps; This joint paper will also be discussed by the } \\
\text { World Bank's Board. }\end{array}$ & $\mathrm{MCM}$ & TB2 \\
\hline \multicolumn{5}{|l|}{ Abbreviations: } \\
\hline DIS: discussion & \multicolumn{4}{|c|}{ Info: for information $\quad$ ISEM: informal seminar } \\
\hline Departments: & \multicolumn{2}{|c|}{ FAD: Fiscal Affairs } & and Capital $\mathrm{N}$ & \\
\hline RES: Research & \multicolumn{4}{|c|}{ SPR: Strategy, Policy, and Review $\quad$ STA: Statistics } \\
\hline $\begin{array}{l}\text { Time band } 1 \text { (TB1): now through } \\
\text { January } 2009\end{array}$ & \multicolumn{2}{|c|}{ Time band 2 (TB2): February-April 2009} & After April & \\
\hline
\end{tabular}


Fall 2008 Work Program Statement

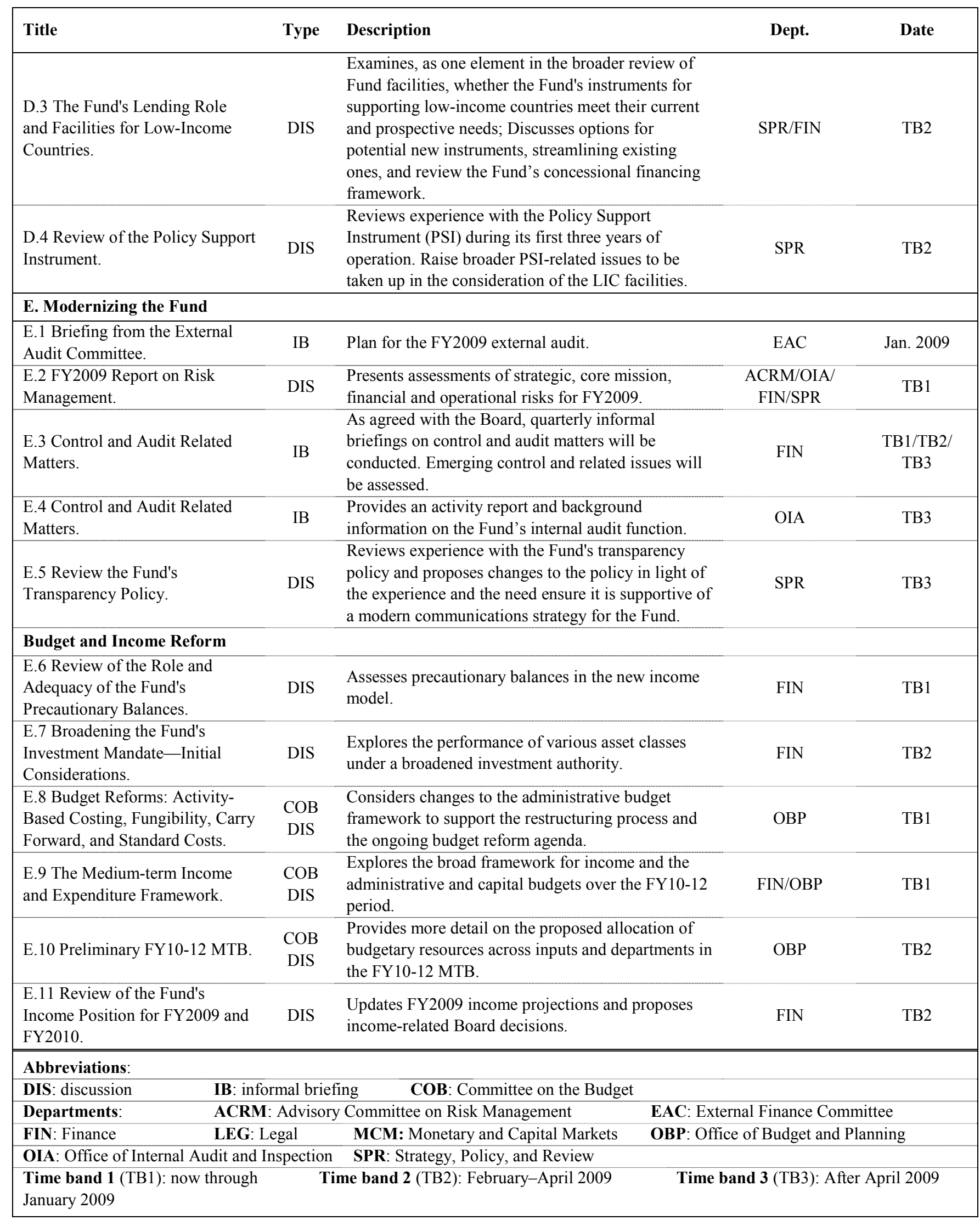


Fall 2008 Work Program Statement

\begin{tabular}{|c|c|c|c|c|}
\hline Title & Type & Description & Dept. & Date \\
\hline \multicolumn{5}{|l|}{ E. Modernizing the Fund } \\
\hline $\begin{array}{l}\text { E.12 FY2010-12 Medium-Term } \\
\text { Administrative, Restructuring } \\
\text { and Capital Budgets. }\end{array}$ & DIS & $\begin{array}{l}\text { Proposes Board decisions regarding the FY10-12 Medium- } \\
\text { term Administrative Budget and the FY10 Capital Budget, } \\
\text { and provides an update of use of resources approved under } \\
\text { the Restructuring Budget. }\end{array}$ & OBP & TB2 \\
\hline \multicolumn{5}{|c|}{ Human Resource Policies and Work Practices } \\
\hline $\begin{array}{l}\text { E.13 Staff Compensation- } \\
\text { Interim Report. }\end{array}$ & DIS & $\begin{array}{l}\text { Provides an update on progress and next steps in } \\
\text { completing the } 2009 \text { compensation review. }\end{array}$ & HRD & Jan. 2009 \\
\hline $\begin{array}{l}\text { E.14 Staff Compensation-2009 } \\
\text { Review. }\end{array}$ & DIS & $\begin{array}{l}\text { Provides the basis for the full comparator-based review of } \\
\text { A1-B5 compensation and the proposed salary-related } \\
\text { Board decisions. }\end{array}$ & HRD & $\begin{array}{l}\text { Mar. } \\
2009\end{array}$ \\
\hline $\begin{array}{l}\text { E. } 15 \text { Medical Benefits Plan- } \\
\text { Contribution Framework and } \\
\text { Increase. }\end{array}$ & DIS & $\begin{array}{l}\text { Presents annual actuarial assessment and proposed } \\
\text { contribution increase for the MBP; Also, reviews RSBIA } \\
\text { governance and subsidies for national health coverage } \\
\text { (Medicare). }\end{array}$ & HRD & $\begin{array}{l}\text { Mar. } \\
2009\end{array}$ \\
\hline \multicolumn{5}{|l|}{ Fund Programs and Lending } \\
\hline $\begin{array}{l}\text { E.16 Review of the Fund's De- } \\
\text { escalation Policy. }\end{array}$ & DIS & $\begin{array}{l}\text { Considers issues related to possible modifications of the } \\
\text { de-escalation policy for members with overdue Fund } \\
\text { financial obligations to make remaining current on new } \\
\text { obligations falling due a firm test of cooperation with the } \\
\text { Fund. }\end{array}$ & FIN & TB3 \\
\hline $\begin{array}{l}\text { E.17 Review of the Safeguards } \\
\text { Assessment Policy. }\end{array}$ & DIS & $\begin{array}{l}\text { This periodic policy review has been delayed to take } \\
\text { account of any changes coming out of the facilities review. }\end{array}$ & FIN & TB3 \\
\hline \multicolumn{5}{|l|}{ IEO Matters } \\
\hline $\begin{array}{l}\text { E.18 Periodic Monitoring } \\
\text { Report. }\end{array}$ & LOT & $\begin{array}{l}\text { Provides an update on progress in the } \\
\text { implementation of Board-endorsed IEO } \\
\text { Recommendations. }\end{array}$ & SPR & TB1 \\
\hline $\begin{array}{l}\text { E.19 IMF's Approach to } \\
\text { International Trade Policy Issues. }\end{array}$ & DIS & $\begin{array}{l}\text { Evaluates the Fund's advice on international trade policy } \\
\text { in light of the institution's stated purpose to facilitate the } \\
\text { expansion and balanced growth of international trade. }\end{array}$ & IEO & TB2 \\
\hline $\begin{array}{l}\text { E. } 20 \text { Management } \\
\text { Implementation Plan for Board- } \\
\text { endorsed IEO Recommendations } \\
\text { on the IMF's Approach to } \\
\text { International Trade Policy. }\end{array}$ & DIS & $\begin{array}{l}\text { Presents management's plan to implement the Board- } \\
\text { endorsed recommendations. }\end{array}$ & SPR & TB3 \\
\hline $\begin{array}{l}\text { E.21 IMF's Interactions with its } \\
\text { Member Countries. }\end{array}$ & DIS & $\begin{array}{l}\text { Evaluates whether the interactions between the IMF and its } \\
\text { member countries have been effective and well managed. }\end{array}$ & IEO & TB3 \\
\hline \multicolumn{5}{|l|}{ Abbreviations: } \\
\hline \multicolumn{5}{|c|}{ DIS: discussion $\quad$ LOT: lapse of time } \\
\hline \multicolumn{2}{|c|}{ Departments: $\quad$ FIN: Finance } & \multicolumn{3}{|c|}{ IEO: Independent Evaluation Office } \\
\hline \multicolumn{5}{|c|}{ OBP: Office of Budget and Planning $\quad$ SPR: Strategy, Policy, and Review } \\
\hline \multicolumn{2}{|l|}{$\begin{array}{l}\text { Time band } 1 \text { (TB1): now through } \\
\text { January } 2009\end{array}$} & \multicolumn{3}{|c|}{ Time band 3 (TB3): After April 2009} \\
\hline
\end{tabular}




\section{Statement by the Managing Director on the Work Program of the Executive Board-Implications of the G-20 Summit November 24, 2008}

1. In setting out an Action Plan for dealing with the crisis in financial markets and the world economy, the declaration that emerged from the G-20 summit emphasized the central role of the Fund as a crisis responder and as a developer of ideas - in conjunction with other entities - for reform of the global financial architecture.

2. The specific expectations with regard to the Fund emerging from the G-20 summit are summarized in Table 1. These are broadly in line with the guidance received from the IMFC, and as such are already incorporated in my statement on the work program. Notable among these are the tasks of drawing the lessons of the crisis and recommending responses, ensuring flexibility in Fund instruments and facilities, and developing an early warning system. However, in some instances, it may be desirable to modify the planned output or to bring it forward in time. For example, on developing recommendations to mitigate procyclicality, we will need to develop more detailed analysis and specific actions than is possible in a broad "lessons" paper and to do so in close collaboration with the expanded FSF. Similarly, the work on early warning systems is being intensified and the planned Board briefing will be upgraded to a more substantive paper on its key elements. The modalities for strengthened collaboration with the expanded FSF will also be explored. In any event, it is clear that the Fund's contributions should emerge from a process of consultation with the Board. Every effort will be made to respect circulation periods and to avoid bunching, but we are working with a smaller staff complement that is dealing with a very ambitious work agenda in a compressed time span.

3. The G-20 is also setting up working groups to develop proposals on a range of issues, including accounting standards, transparency in derivative markets, compensation and regulatory procyclicality, oversight of systemic institutions, and the governance of the IFIs. (These are set out in paragraph 10 of the Summit Declaration.) The composition and modalities of these working groups have yet to be defined by the G-20, but we stand ready to contribute fully to the efforts of these working groups, including through the outputs listed in right hand column of Table 1. (This column also contains cross references to the relevant paragraph in my Statement circulated on November 6, 2008.) Given that the G-20 summit concluded less than a week ago, the listed outputs should be viewed at this stage as preliminary. We will also need to consider further the appropriate modalities to involve the Board in a timely manner. 
Table 1

G20 Action Plan as it Pertains to IMF and Work Program Outputs

G20 Action Plan

1 They [our finance Ministers] are responsible for the development and implementation of these recommendations drawing on the ongoing work of relevant bodies, including the International Monetary Fund (IMF), an expanded Financial Stability Forum (FSF), and standard setting bodies.

2 [Immediate Actions by March 31, 2009] The IMF, expanded FSF, and other regulators and bodies should develop recommendations to mitigate pro-cyclicality, including the review of how valuation and leverage, bank capital, executive compensation, and provisioning practices may exacerbate cyclical trends.

3 ... all G-20 members commit to undertake a Financial Sector Assessment Program (FSAP) report and support the transparent assessments of countries' national regulatory systems.

4 The appropriate bodies should review the differentiated nature of regulation in the banking, securities, and insurance sectors and provide a report outlining the issue and making recommendations on needed improvements. A review of the scope of financial regulation, with a special emphasis on institutions, instruments, and markets that are currently unregulated, along with ensuring that all systemically-important institutions are appropriately regulated, should also be undertaken.

5 [Immediate Actions by March 31, 2009] The IMF, with its focus on surveillance, and the expanded FSF, with its focus on standard setting, should strengthen their collaboration, enhancing efforts to better integrate regulatory and supervisory responses into the macro-prudential policy framework and conduct early warning exercises.

6 [Immediate Actions by March 31, 2009] The IMF, given its universal membership and core macro-financial expertise, should, in close coordination with the FSF and others, take a leading role in drawing lessons from the current crisis, consistent with its mandate.

7 [Immediate Actions by March 31, 2009] We should review the adequacy of the resources of the IMF, the World Bank Group and other multilateral development banks and stand ready to increase them where necessary.
Next Steps in Fund Work Program

G20 troika to establish modalities for working groups - Fund inputs to be determined, (TB2).

"Lessons" paper to touch on issues related to pro-cyclicality (\$5).

In addition, MCM to prepare a staff report in coordination with FSF (TB2).

Requires consultations with authorities and World Bank counterparts. Board to be informed (TB1).

Already in work program-issues partly covered in the "lessons" paper ( $\$ 5)$.

MCM to liaise with the FSF and G20 interlocutors on expanded paper, (TB2).

Already in work program (\$7). Planned Board briefing on progress with early warnings will be expanded to Board paper prepared jointly by MCM/RES/SPR, (TB1/TB2).

Addressed in work program ( $₫ 5)$ by "lessons" paper, (TB1/TB2)

A paper will be prepared to examine IMF resource needs and options for supplementing those needs, including the recent offer by Japan (TB1/TB2), 
Table 1

G20 Action Plan as it Pertains to IMF and Work Program Outputs (concluded)

\section{G20 Action Plan \\ 8 [Immediate Actions by March 31, 2009] The IFIs should also continue to review and adapt their lending instruments to adequately meet their members' needs and revise their lending role in the light of the ongoing financial crisis.}

9 We underscored that the Bretton Woods Institutions must be comprehensively reformed so that they can more adequately reflect changing economic weights in the world economy and be more responsive to future challenges. Emerging and developing economies should have greater voice and representation in these institutions.

10 The IMF should conduct vigorous and even-handed surveillance reviews of all countries, as well as giving greater attention to their financial sectors and better integrating the reviews with the joint IMF/World Bank financial sector assessment programs. On this basis, the role of the IMF in providing macro-financial policy advice would be strengthened.

11 Advanced economies, the IMF, and other international organizations should provide capacity-building programs for emerging market economies and developing countries on the formulation and the implementation of new major regulations, consistent with international standards.

\section{Next Steps in Fund Work Program}

Already addressed in work program (\4): Review of Facilities, (TB1/TB2)

First stage of reform already approved by Board; domestic legislative actions by national authorities are pending ( $(8)$. Additional work on governance reform is in train (\$14).

Informal Board seminar on integrating financial sector issues into surveillance will be added (TB1/TB2). See also $\$ 11$.

New Board paper to address these issues, (TB2) 